him most, and his investigation into the life of the former was an almost classic example of the statistical use of a vast mass of metallurgical evidence. The many problems connected with the locomotive boiler also held a great appeal, and he could never resist the temptation to inspect personally any boiler that had developed some peculiar defect in service. Even on his many visits abroad, he invariably took his boilersuit with him and excited the admiration of his hosts (and of the writer) by his skill in negotiating the not always easy entrance to the barrel or firebox of a locomotive. Therein he showed how thoroughly he understood the value of personal observation, which is so essential in engineering and metallurgical research.

T. M. H.

\section{Prof. P. A. Murphy}

Paul Aloysius Murphy, whose death at the age of fifty-one years occurred on September 27, was born in Co. Kilkenny. After courses at the Albert Agricultural College, Glasnevin, and the Royal College of Science, Dublin, extending over five years, he was appointed to a temporary post under the Irish Department of Agriculture and started research in plant pathology. Later, with a Development Commission scholarship, he proceeded to the Imperial College of Science and Technology, London, and to the K. Biologische Reichsanstalt, in Berlin-Dahlem. Leaving Germany in 1914, and being rejected on medical grounds for active service, he completed his scholarship period at Cornell University. He was then appointed plant pathologist in Prince Edward Island by the Canadian Government. He returned to Ireland in 1921 to similar work in the Department of Agriculture there, and six years later was appointed to the newly created chair of plant pathology in University College, Dublin, which he held until his death.

Murphy's scientific work was very largely concerned with research on potato diseases. After having helped to show the bacterial nature of the so-called 'black leg' disease and to prove that the blight fungus (Phytophthora infestans) was capable of producing sexual spores-a much-vexed problem up to that time-he worked out the cytology of the peculiar mode of sexual reproduction in the newly discovered allied species $P$. erythroseptica. Later, he considerably extended his work on the bionomics of $P$. infestans, but devoted much attention to virus diseases such as leaf roll, mosaic, crinkle and streak. His contributions to a scientific knowledge of these obscure diseases were particularly extensive and important, and received world-wide recognition. As a result of his investigations and those of a few other pioneers, the production of healthy stocks of potatoes has been placed on a sound scientific basis, and important advantages to practical agriculture have already accrued. To mark his eminent work in the sphere of potato husbandry, Murphy was awarded the John Snell Memorial Medal by the National Institute of Agricultural Botany in 1927.

At his old college at Glasnevin (now incorporated with University College, Dublin) Murphy developed a vigorous school of plant pathology, and the sound work of himself and his colleagues there, not only on virus diseases but also on others, such as onion mildew, swede dry rot, sugar-beet crown rot and American gooseberry mildew, is a testimony to its wide scope and to Murphy's inspiring and untiring devotion to research in plant pathology.

Murphy graduated at the University of Dublin (Trinity College) in his student days and was awarded the Sc.D. degree in 1922. He was a member of the Royal Dublin Society and a valued member of its Science Committee. For his published researches, the Society awarded him the Boyle Medal in 1933, and at the time of his death these were approaching fifty in number. He was also a member of the Royal Irish Academy, of the Phytopathological Society of America and of the Agricultural Research Council's Committee on Virus Diseases of Plants.

Murphy's loss will be deplored in wide circles, for he was always ready to help other workers. Many of them, both at home and abroad, will gratefully remember his generosity in the distribution of strictly dependable material - the product of his own careful and protracted work-which greatly facilitated their own investigations. $\mathrm{He}$ leaves a widow and two sons, for whom the deepest sympathy is felt.

G. H. P.

Mr. Rosse Butterfield, of High Cote, Riddlesden, Yorkshire, curator of the Keighley (Yorkshire) Corporation Museum, who died recently at the age of sixty-four years, was a well-known naturalist of the West Riding. He came of a Wilsden family of naturalists and his father was a well-known authority; another member of the family was the late Mr. Ruskin Butterfield, formerly curator of the Hastings Museum. Mr. Rosse Butterfield did much valuable work in connexion with organizations of naturalists, and he was himself known for his work in entomology. He had been the curator at Keighley Museum since 1910 and was due to retire next year. Under his guidance the development of the Museum collections and of education in natural history has made rapid strides. He was a member of the executive of the Yorkshire Naturalists' Union and was secretary of the Keighley Naturalist Society. He was a member of the committee of the Bradford Natural History and Microscopical Society and was recorder for Hymenoptera. Formerly, Mr. Butterfield was curator of the Bronte Museum at Haworth.

WE regret to announce the following deaths :

Sir James Barr, C.B.E., consulting physician to the Liverpool Royal Infirmary, known for his work on the diseases of the blood vascular system, on November 16, aged eighty-nine years.

Prof. J. W. Bews, principal of Natal University College and professor of botany in the College, aged fifty-three years.

Prof. William McDougall, F.R.S., professor of psychology in Duke University, North Carolina, aged sixty-seven years. 